\title{
Iron Deficiency: A New Target for Patients With Heart Failure
}

\author{
Caterina Rizzo ${ }^{*}$, Rosa Carbonara ${ }^{\dagger}$, Roberta Ruggieri ${ }^{\dagger}$, Andrea Passantino $^{\dagger}$ and \\ Domenico Scrutinio ${ }^{+}$
}

Department of Cardiology, Istituti Clinici Scientifici Maugeri, IRCCS, Bari, Italy

\section{OPEN ACCESS}

Edited by:

Filippo M. Sarullo,

Ospedale Buccheri la Ferla

Fatebenefratelli, Italy

Reviewed by:

Gaetano Antonio Lanza, Catholic University of the Sacred

Heart, Italy

Guido Pastorini,

Regina Montis Regalis Hospital, Italy

*Correspondence:

Caterina Rizzo

caterina.rizzo@icsmaugeri.it

tThese authors have contributed equally to this work and share first

authorship

Specialty section:

This article was submitted to

Heart Failure and Transplantation,

a section of the journal

Frontiers in Cardiovascular Medicine

Received: 14 May 2021

Accepted: 19 July 2021

Published: 10 August 2021

Citation:

Rizzo C, Carbonara R, Ruggieri R,

Passantino A and Scrutinio D (2021)

Iron Deficiency: A New Target for

Patients With Heart Failure.

Front. Cardiovasc. Med. 8:709872.

doi: 10.3389/fcvm.2021.709872
Iron deficiency (ID) is one of the most frequent comorbidities in patients with heart failure (HF). ID is estimated to be present in up to $50 \%$ of outpatients and is a strong independent predictor of HF outcomes. ID has been shown to reduce quality of life, exercise capacity and survival, in both the presence and absence of anemia. The most recent 2016 guidelines recommend starting replacement treatment at ferritin cutoff value $<100 \mathrm{mcg} / \mathrm{l}$ or between 100 and $299 \mathrm{mcg} / \mathrm{l}$ when the transferrin saturation is $<20 \%$. Beyond its effect on hemoglobin, iron plays an important role in oxygen transport and in the metabolism of cardiac and skeletal muscles. Mitochondria are the most important sites of iron utilization and energy production. These factors clearly have roles in the diminished exercise capacity in HF. Oral iron administration is usually the first route used for iron repletion in patients. However, the data from the IRONOUT HF study do not support the use of oral iron supplementation in patients with $\mathrm{HF}$ and a reduced ejection fraction, because this treatment does not affect peak $\mathrm{VO}_{2}$ (the primary endpoint of the study) or increase serum ferritin levels. The FAIR-HF and CONFIRM-HF studies have shown improvements in symptoms, quality of life and functional capacity in patients with stable, symptomatic, iron-deficient HF after the administration of intravenous iron (i.e., FCM). Moreover, they have shown a decreased risk of first hospitalization for worsening of HF, as later confirmed in a subsequent meta-analysis. In addition, the EFFECT-HF study has shown an improvement in peak oxygen consumption at CPET (a parameter generally considered the gold standard of exercise capacity and a predictor of outcome in $\mathrm{HF}$ ) in patients randomized to receive ferric carboxymaltose. Finally, the AFFIRM AHF trial evaluating the effects of FCM administration on the outcomes of patients hospitalized for acute HF has found significantly fewer hospital readmissions due to HF among patients treated with FCM rather than placebo.

Keywords: chronic heart failure, acute heart failure, iron deficiency, anemia, ferric carboxy maltose, hemoglobin, iron deficiency anemia

\section{INTRODUCTION}

Heart failure (HF) is a major cause of morbidity and mortality worldwide, and a growing public health problem: the incidence of HF with reduced ejection fraction is $1-2 \%$ in the general population and as high as $10 \%$ in the population over 65 years of age.

Patients with HF have many comorbidities that affect their quality of life, clinical management and prognosis (1); however, treatment of comorbidities does not always improve patients outcomes; 
for example, anemia treatment with agents stimulating erythropoiesis have not demonstrated any benefit in HF or sleep related breathing disorders. On the other hand, the HF course can be improved through treatment of iron deficiency (ID) with ferric carboxymaltose (FCM) and of diabetes with SGLT2 inhibitors.

This review describes the prevalence, clinical implications, and possible advantages of treating iron deficiency in HF.

\section{DEFINITION OF IRON DEFICIENCY}

ID is defined as a "health-related condition in which iron availability is insufficient to meet the body's needs and which can be present with or without anemia" (2).

In daily clinical practice, simple tests used for the diagnosis of ID include serum ferritin, serum iron, transferrin and transferrin saturation (TSAT); however, the best cutoff index for ID remains unclear.

It is useful to distinguish absolute ID, in which a real deficit of iron stores exists, and functional deficiency, in which the iron stores are normal, but the transport of iron to target cells is deficient (3). In functional deficiency, the interpretation of serum ferritin levels may be challenging. In the presence of inflammation, ferritin, an acute phase protein, may become elevated; therefore, in patients with HF, in whom low-grade inflammation is present, ferritin dosage may be not suitable to identify ID. Nanas et al. have found that some patients with $\mathrm{HF}$ and anemia have ID (as evaluated by bone marrow biopsy) despite having normal serum ferritin levels (4).

The cutoff values at which replacement treatment is recommended, according to the most recent 2016 ESC guidelines, are a ferritin value $<100 \mathrm{mcg} / \mathrm{l}$ (absolute ID) or is between 100 and $299 \mathrm{mcg} / \mathrm{l}$ when the TSAT is $<20 \%$ (functional ID) (5). Treatment should be considered regardless of the presence of anemia. Although these cutoff values were not previously validated, they have been used in clinical trials in which IV ion supplementation has been found to be clinically successful; consequently, they are now largely accepted.

The gold standard for identifying ID is bone marrow iron staining. Using this method, which requires bone marrow aspiration from the sternum, Grote Beverborg et al. have validated the definition of ID according to biomarkers. Fortytwo patients with HF undergoing sternotomy for coronary bypass were studied. Iron staining was performed on bone marrow aspirated from the sternum, and iron stores were accurately measured. The ESC definition of ID had a sensitivity of $94 \%$ and a specificity of $72 \%$ for identifying ID. A TSAT $\leq 19.8$ was the best cutoff, together with serum iron $\leq 13$ $\mu \mathrm{mol} / \mathrm{L}$; the areas under the ROC curves were 0.932 a 0.922 , respectively (6). These experimental data have confirmed the accuracy of a cutoff of $20 \%$ for TSAT, although they prompt the question of whether serum ferritin is a reliable diagnostic marker for ID.

A major limitation of the ESC definition of ID is the exclusion of patients with ferritin $>300 \mu \mathrm{g} / \mathrm{ml}$ and TSAT $\leq 20 \%$.

\section{PREVALENCE}

Because ID is the most widespread nutritional disorder worldwide, its high prevalence in patients with $\mathrm{HF}$ is unsurprising. In that population, the ID prevalence is estimated to be between 35 and 55\%. The prevalence of ID is higher in women than men, and it increases with worsening of the NYHA functional class (7).

ID is common regardless of the presence of anemia (8).

In patients with acutely decompensated $\mathrm{HF}$, the prevalence is even higher, ranging from 72 to $83 \%$ (9). Absolute ID is more prevalent than relative ID in both acute and chronic HF.

The variability among studies may be explained by the different characteristics of the enrolled populations (some studies included only anemic patients) and by the choice of ID definition. When ID was identified by the most reliable method, bone marrow staining, the prevalence has been found to be $40 \%$ (6).

\section{PATHOPHYSIOLOGY OF IRON DEFICIENCY}

Iron is the most important and abundant trace element in the human body ( $3-5 \mathrm{~g}$ overall), it is absorbed in the gut, delivered to tissues for erythropoiesis or other functions, deposited in reticuloendothelial cells and lost through epithelial desquamation or bleeding (10). Iron accumulation is toxic and can potentially result in the generation of reactive oxidative species (ROS), which can damage all cell components (11).

Physiological iron metabolism involves transferrin and ferritin. Transferrin is a plasma protein that transports iron through the blood circulation. Iron enters cells through transferrin receptor type 1 via receptor-mediated endocytosis; in the cytoplasm, iron is used to synthetize heme-groups, cytochromes and other Fe-dependent proteins involved in oxygen transport and oxidoreductive reactions (12). In contrast, ferritin enables iron storage.

Both ferritin and transferrin also act as "detoxifiers" in cells and vessels, respectively: they bind ferrous iron $\left(\mathrm{Fe}^{2+}\right)$ and thereby prevent its conversion to the ferric isoform $\left(\mathrm{Fe}^{3+}\right)$ and the concomitant reduction of molecular oxygen, thus leading to ROS formation (13).

Iron is fundamental in aerobic metabolism being the key component of hemoglobin and myoglobin, the main proteins for $\mathrm{O}_{2}$ transport and accumulation, respectively. Proteins involved in oxidative energy generation contain iron in their prosthetic groups. Oxidoreductive reactions occur in the cytoplasm via the citric acid cycle and in the mitochondria via the respiratory chain-two central pathways in cellular energy generation (10).

In the citric acid cycle, the conversion of citrate to isocitrate involves a chemical reaction mediated by aconitase. This enzyme has a ferro-sulfo (Fe-S) center, which is sensitive to iron levels (14). Low iron levels result in the loss of iron atoms in Fe$S$ clusters and the stimulation of trasferrin-receptor-1 mRNA transcription (15).

In the respiratory chain, cytochromes and $\mathrm{Fe}-\mathrm{S}$ proteins serve as electron transporters in the mitochondrial membrane, 
and both use iron in prosthetic heme-groups or Fe-S cluster proteins (12).

As described above, iron is involved in crucial metabolic cell reactions, owing to its ability to bind oxygen $\left(\mathrm{O}_{2}\right)$.

Iron acts as an electron transporter in key sites of $\mathrm{O}_{2}$ utilization, such as the mitochondria, which are abundant in heart tissue and skeletal muscle, and produce energy for contraction. Consequently, metabolism in tissues with high energetic demand is strictly dependent on iron homeostasis. An unfavorable catabolic-anabolic balance with a metabolic switch toward anaerobic glycolysis in muscular tissue is responsible for decreased exercise capacity (12).

Cultured human stem cell-derived cardiomyocytes subjected to ID exhibit diminished basal respiration, owing to respiratory chain dysfunction. In this in vitro model, mitochondria show aberrant structures and localization in cells after the activation of a hypoxic response. The final switch from fatty acid oxidation to anaerobic glycolysis can be rescued by iron restoration (16).

In a mouse model, targeted disruption of transferrin receptor-1 in cardiomyocytes induces early lethal cardiomyopathy, owing to mitochondrial failure and dysfunctional mitochondrial clearance, which contribute to a switch toward anaerobic metabolism. This cardiomyopathy might be prevented by aggressive and continuous iron supplementation (17).

\section{Principal Mechanisms of ID}

ID may have a negative effect on the generation of cellular energy, particularly in cells with high metabolic demand. In HF, ID can contribute to a shift toward anaerobic metabolism. Clinically, ferritin and transferrin saturation blood levels provide information about iron homeostasis, because their synthesis is dependent on iron availability.

Absolute ID is clinically defined by a ferritin level $<100 \mathrm{ng} / \mathrm{ml}$, which indicates a decrease in total body iron stores. Its etiology is based on interference with iron transport throughout the body. Three main mechanisms underlie the deficiency: low iron intake, which depends on the diet; decreased iron absorption, which is associated with gastrointestinal abnormalities; and increased iron loss, owing to hemorrhages or proteinuria.

High levels of proinflammatory cytokines can trigger "iron trapping" in macrophages, hepatocytes and enterocytes, through the degradation of ferroportin, the transmembrane protein for iron transport outside cells. This mechanism usually protects against microorganisms, which depend on iron availability for survival, and it promotes a functional state of ID, thus making iron unusable despite sufficient iron stores. This pathological state is clinically defined by ferritin levels $<300 \mathrm{ng} / \mathrm{ml}$ with TSAT $\leq 20 \%(18,19)$.

Low TSAT can also be used to identify patients with absolute ID in the case of high levels of ferritin, which usually acts as a non-specifically acute-phase reactant.

In HF, both types of deficiency can occur (18). Renal dysfunction necessitates a low protein-diet with a consequent low iron intake. In renal dysfunction, proteinuria is frequently observed and also involves Feproteins. Antiaggregant/anticoagulant therapies are potentially responsible for gastritis or duodenitis, thereby increasing iron loss. Low arterial blood flow or venous blood accumulation in edema conditions characterize different stages of HF or can coexist in the same phase. Consequently, decreased iron absorption through the enteric edematous mucosa is one mechanism underlying ID in HF. The increasing use of protonpump inhibitors impairs the process of iron absorption, which is optimal at lower $\mathrm{pH}$ in its reduced form $\mathrm{Fe}^{2+}$. Other medications prescribed for HF can decrease hematopoietic activity, such as angiotensin-converting enzyme inhibitors or carvedilol $(13,18,19)$.

A chronic proinflammatory state is present in $\mathrm{HF}$, as confirmed by the high levels of IL-6, TNF-alpha, and INFgamma found in patients with HF. Inflammation increases the release of hepcidin, a key liver regulatory protein promoting the degradation of the membrane iron exporter ferroportin (11). Furthermore, enhanced expression of pro-inflammatory cytokines in $\mathrm{HF}$ has been correlated with inhibition of erythropoiesis, through elevated levels of negative regulators of hematopoietic stem cells (20).

Together, these mechanisms cause low levels of iron, independently of the level of iron stores. Over time, ID can cause anemia, a common comorbidity in patients with HF.

Anemia and ID share common causes (21). Anemia in HF is usually due to multiple factors, including hypoplastic bone marrow (particularly in older people), inadequate erythropoiesis (vitamin deficiency, low erythropoietin levels, and blunted erythropoietin production) or increased blood loss (hemorrhage and frequent venipuncture, as are common in HF) (22). Another possibility for consideration early in HF is pseudo-anemia, which results from fluid retention with increased extracellular volume (20).

\section{CLINICAL IMPLICATIONS OF ID}

Low levels of iron are independently associated with diminished exercise tolerance in HF, even in the absence of anemia. In patients with HF, ID correlates with a diminished peak oxygen consumption $\left(\mathrm{VO}_{2}\right.$ peak) and an increased ventilatory response $\left(\mathrm{VE} / \mathrm{VCO}_{2}\right.$ slope) in cardiopulmonary exercise tests.

In 27 patients, Okonko et al. have found a lower $\mathrm{VO}_{2}$ peak measured during maximal cardiopulmonary tests in patients with ID compared with iron-replete patients.

Aerobic capacity was correlated with TSAT and ferritin, independently of NYHA functional class and hemoglobin level. In addition, the ventilatory response to exercise, expressed as the $\mathrm{VE} / \mathrm{VCO}_{2}$ slope, was correlated with TSAT (23).

In a larger sample, Ebner et al. have found a diminished maximal aerobic capacity in patients with ID without anemia; in patients with both anemia and ID, the capacity was even lower (24).

Beyond its roles in decreasing exercise capacity (25) and quality of life (26), ID has been demonstrated to be a predictor of prognosis for death and hospitalizations (27). 
In several survival studies, ID has been associated with an increased rate of hospitalization and mortality regardless of the presence of anemia (9), despite major differences in the methods chosen to evaluate ID in the prognostic studies.

During a 743-day follow-up, in 157 patients with chronic $\mathrm{HF}$ and a left ventricular ejection fraction $\leq 45 \%$, a TSAT $\leq 20 \%$ has been found to be an independent predictor of event free survival. Iron-deficient patients had a 3 -fold greater risk of death regardless of whether they were anemic. Patients with ID but without anemia had a 2 -fold greater risk of mortality (23).

In an international pooled analysis including 1,506 patients with $\mathrm{CHF}$ (with both preserved and reduced ejection fraction) from five cohorts, ID has been found to be a strong predictor of mortality. In multivariable hazard models, ID (defined by ESC criteria), but not anemia, has been found to be a strong independent predictor of mortality (hazard ratio 1.42, 95\% confidence interval 1.14-1.77, $p=0.002$ ). Furthermore, ID has been found to significantly improve risk classification and integrated discrimination when added to a predictive model incorporating established risk factors (8).

In a study population of 387 patients with $\mathrm{HF}$ with reduced ejection fraction, both TSAT $\leq 19.8 \%$ and serum iron $\leq 13$ $\mu \mathrm{mol} / \mathrm{l}$ (ID criteria validated by bone marrow staining) have been found to be predictors of death during a 2 year follow-up, whereas isolated low ferritin was not associated with the risk of death (6).

In 2,356 patients with worsening $\mathrm{HF}$, low iron storage (defined by a bone marrow-validated combination of transferrin saturation $<20 \%$ and a serum ferritin concentration of $128 \mathrm{ng} / \mathrm{mL}$ or less) has been associated with HF prognosis. In the same population, defective iron utilization (defined by a TSAT $<20 \%$ and a serum ferritin concentration $>128 \mathrm{ng} / \mathrm{mL}$ ) did not predict outcome (28).

Recently, Campodonico et al. have reported that patients with a TSAT $\leq 20 \%$, independently of ferritin levels, had poorer prognosis than those with TSAT $\geq 20 \%$ during a 2 year followup. When patients were dived according to ferritin level, the group with both composite ferritin between 100 and $300 \mathrm{mg} / \mathrm{L}$ and TSAT $<20 \%$ identified patients with HF with the poorest survival rate (29).

ID is prevalent in patients with acute HF. Among patients hospitalized for acute HF, absolute ID, compared with functional ID and no ID, has been associated with an increased rate of readmission $(19.9,13$, and $13.5 \%$, respectively, $P=0.005)$. Absolute ID remained associated with clinical outcome after correction for other variables (30).

However, at odds with these results, ID has not been found to predict mortality or hospitalization after adjustment for comorbidities in a real life population of 1,684 patients with $\mathrm{HF}$ (31). According to the authors, the high percentage of patients with a preserved ejection fraction in the study population may account for this finding.

In 165 patients hospitalized for acute HF, ID, defined by low levels of serum hepcidin and high serum soluble transferrin receptors, has been found to be a significant and independent predictor of 12-month mortality (32).
Causes and consequences of ID in HF are summarized in Figure 1.

\section{IRON TREATMENT IN PATIENTS WITH CHRONIC HF}

\section{Changing the Target: From Anemia to ID}

In the past, the treatment of anemia, a relevant comorbidity in $\mathrm{HF}(33,34)$, by increasing red blood cell synthesis through erythropoietin (EPO) administration in HF patients, has been considered a valuable strategy (35-37).

After encouraging results from some preliminary, small studies (38-42), following larger trials, did not demonstrated any clinical improvement after EPO administration. In contrast, an increased risk of ischemic stroke and embolic events was recorded in patients treated with darbepoetin (43-45).

After these disappointing results, ID was identified as a new possible therapeutic target in HF. The main trials with iron supplementation in HF are reported in the Table $\mathbf{1 .}$

\section{Oral Iron Supplementation}

The Short Term Oral Iron Supplementation in Systolic Heart Failure Patients Suffering From Iron Deficiency Anemia (IRON$5 \mathrm{HF}$ ) trial has evaluated the use of oral iron administration. Unfortunately, the trial was terminated early after prolonged recruitment and funding problems.

The Oral Iron Repletion Effects On Oxygen Uptake in Heart Failure (IRONOUT HF) trial, also testing oral iron administration, was a double-blind, randomized, placebocontrolled trial of 225 patients with HF, an LVEF $<40 \%$ and ID, defined by a ferritin concentration of 15 to $100 \mathrm{mg} / \mathrm{l}$, or ferritin $101-299 \mathrm{mg} / \mathrm{l}$ with TSAT $<20 \%(46)$.

The primary endpoint, a change in peak oxygen uptake from baseline to 16 weeks, did not differ between groups at the end of the follow-up. Likewise, no significant changes were found for the secondary endpoints of 6-min walking tests (6MWT) and NT-proBNP levels.

Moreover, oral iron supplementation was limited by collateral effects: approximately $40 \%$ of patients receiving oral iron preparations experienced adverse effects, such as nausea, flatulence, abdominal pain, diarrhea, constipation, and black stools.

\section{Intravenous Iron Supplementation}

The Ferric Iron Sucrose in Heart Failure (FERRIC-HF) trial tested the hypothesis that iron repletion alone would improve exercise tolerance in anemic and non-anemic patients with symptomatic CHF and ID. Thirty-five patients with CHF (age 64 \pm 13 years, $\mathrm{VO}_{2}$ peak $14.0 \pm 2.7 \mathrm{ml} / \mathrm{kg} / \mathrm{min}$ ) were randomized to 16 weeks of intravenous iron or no treatment. The ferritin was required to be $<100 \mathrm{ng} / \mathrm{ml}$, or $100-300 \mathrm{ng} / \mathrm{ml}$ with TSAT $<20 \%$. Intravenous iron treatment improved exercise capacity and symptoms. The benefits were more evident in patients with anemia (47).

The Ferinject Assessment in patients with IRon deficiency and chronic Heart failure (FAIR HF) trial was the first largescale, double-blind, placebo-controlled multicenter trial of FCM 


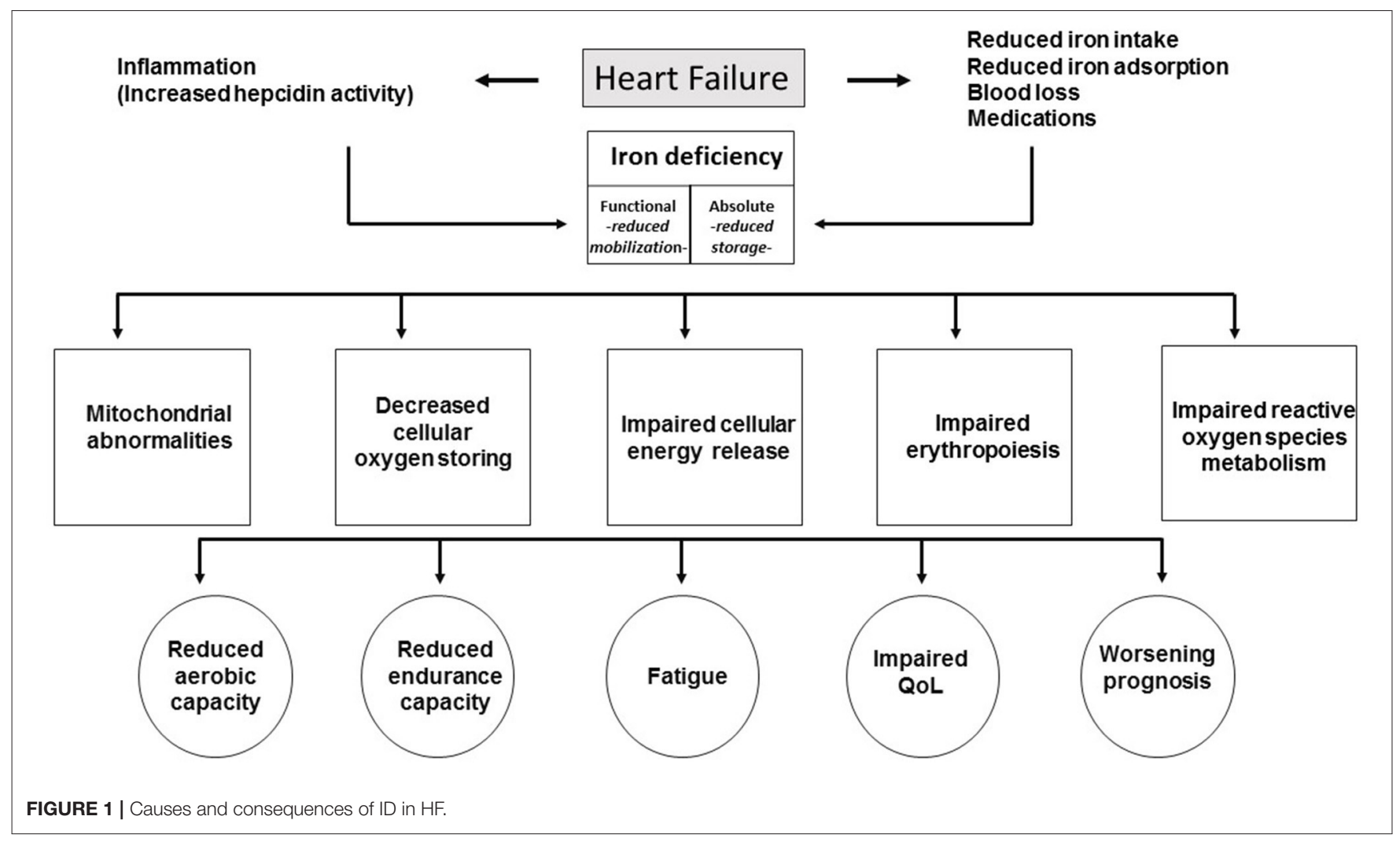

in patients with chronic HF (48). The trial recruited 459 patients with HF with reduced ejection fraction, in NYHA functional class II or III, for a follow-up period of 6 months. Patients were required to have ID, defined by serum ferritin $<100 \mathrm{mg} / \mathrm{l}$, or ferritin ranging from 100 to $300 \mathrm{mg} / \mathrm{l}$ with TSAT $<20 \%$. Patients were randomly allocated in a 2:1 fashion to receive intravenous infusion (IV) of FCM or placebo. The study drug was given in doses based on the participant weight and $\mathrm{Hb}$ value at screening. FCM was administered weekly during the correction phase until iron repletion was obtained, then every 4 weeks during the maintenance phase.

The study demonstrated that IV FCM improved the primary endpoint of quality of life, according to the self-reported PGA and NYHA class. At week 24, when primary endpoints were evaluated, in the FCM group, $47 \%$ of patients were in NYHA class I or II, as compared with $30 \%$ in the placebo group (odds ratio for improvement by one class 2.40; CI 1.55-3.71; $p<0.0001$ ).

Secondary endpoints, including PGA and NYHA functional class at weeks 4 and 12, and 6-min walk distance, likewise showed a statistically significant improvement.

The benefit of FCM treatment in the primary endpoint was similar in patients with and without anemia.

After the publication of the FAIR HF trial, the 2012 ESC guidelines on HF (49) considered ID a relevant comorbidity that influences patient outcomes.

The FCM evaluation on perFormance in patients with IRon deficiency in coMbination with chronic Heart Failure (CONFIRM-HF) trial (50) was the second large-scale trial of FCM in HF. In this multicenter, randomized double-blind study,
304 patients with ejection fraction $<45 \%$ and elevated BNP levels were enrolled. Patients were randomized to FCM or placebo. The follow-up was 1 year ( 6 months longer than that in the previous FAIR-HF study). Participants who received FCM showed an improvement of functional capacity and quality of life and a decrease in hospitalization for worsening of $\mathrm{HF}$, regardless of anemia. For the first time, functional capacity (the primary endpoint) was assessed with an objective test: the 6MWT. A significant difference in $6 \mathrm{MWT}$ at week 24 was observed in the FCMM group vs. the placebo group (difference FCM vs. placebo: $33 \pm 11 \mathrm{~m} ; p=0.002$ ).

The study confirmed the safety profile of FCM: there were no differences in investigator reported adverse events, serious adverse events and adverse event leading to a further update to the guidelines for HF in 2016 (5).

The Effect of ferric carboxymaltose on exercise capacity in patients with chronic heart failure and iron deficiency (EFFECT$\mathrm{HF}$ ) study (51) showed that FCM also improves the $\mathrm{VO}_{2}$ peak, as measured by CPET. In this randomized study, in a nonblinded fashion, 172 patients in NYHA class II or III, with ejection fraction $<45 \%$ and $\mathrm{VO}_{2}$ peak between 10 and 20 $\mathrm{ml} / \mathrm{kg} / \mathrm{min}$, as measured by CPET, were enrolled and followed for 6 months. The primary endpoint was the improvement in the $\mathrm{VO}_{2}$ peak at the end of the study. This result has been documented in patients receiving $\mathrm{EV}$ iron, but it was not significant. The probable explanation for these results is a bias in patient selection (non-blinded study) leading to higher mortality in the control arm and therefore to a smaller amount of obtainable data. 
TABLE 1 | Main trials of iron supplementation in heart failure.

\begin{tabular}{|c|c|c|c|c|c|c|}
\hline Trial & Pts (n) & Design & Study drug & Inclusion criteria & $\begin{array}{l}\text { Primary } \\
\text { endpoint }\end{array}$ & Results \\
\hline IRON-5 HF & 54 & $\begin{array}{l}\text { Double blind } \\
\text { randomized } \\
\text { controlled }\end{array}$ & $\begin{array}{l}\text { Oral ferrous sulfate } \\
200 \mathrm{mg} \text { t.i.d for } 90 \text { days }\end{array}$ & $\begin{array}{l}\text { LVEF }<50 \% \\
\text { NYHA II-III (able to } \\
\text { perform 6MWT) }\end{array}$ & Change 6MWT & Terminated early \\
\hline IRONOUT HF & 225 & $\begin{array}{l}\text { Phase } 2 \\
\text { double-blind } \\
\text { placebo-controlled } \\
\text { randomized }\end{array}$ & $\begin{array}{l}\text { Oral iron } \\
\text { polysaccharide } 150 \mathrm{mg} \\
\text { twice daily for } 16 \\
\text { weeks }\end{array}$ & $\begin{array}{l}\text { LVEF } \leq 40 \% \text { with } \\
\text { NYHA II through IV } \\
\text { symptoms }\end{array}$ & $\begin{array}{l}\text { Change in peak } \\
\mathrm{VO}_{2} \text { from baseline } \\
\text { to } 16 \text { weeks }\end{array}$ & $\begin{array}{l}\text { High-dose of oral } \\
\text { iron did not } \\
\text { improve exercise } \\
\text { capacity over } 16 \\
\text { weeks }\end{array}$ \\
\hline FERRIC HF & 35 & $\begin{array}{l}\text { Randomized } \\
\text { controlled } \\
\text { observer-blinded }\end{array}$ & $\begin{array}{l}\text { IV iron sucrose weekly } \\
\text { for } 16 \text { weeks (Each } \\
\text { dose was administered } \\
\text { as } 200 \text {-mg aliquots in } \\
50 \mathrm{ml} \text { normal saline } \\
\text { infused over } 30 \mathrm{~min} \text { ) }\end{array}$ & $\begin{array}{l}\text { CHF (NYHA II or III) } \\
\text { with LVEF } \leq 45 \%\end{array}$ & $\begin{array}{l}\text { Change in } \\
\text { absolute } \mathrm{pVO}_{2}\end{array}$ & $\begin{array}{l}\text { Intravenous iron } \\
\text { loading improved } \\
\text { exercise capacity } \\
\text { and symptoms }\end{array}$ \\
\hline CONFIRM HF & 304 & $\begin{array}{l}\text { Double-blind } \\
\text { placebo-controlled } \\
\text { randomized }\end{array}$ & $\begin{array}{l}\text { FCM solution given as } \\
\text { undiluted bolus i.v., } \\
\text { injections of } 500 \text { or } \\
1,000 \mathrm{mg} \text { of iron, } \\
\text { administered over at } \\
\text { least } 1 \text { min }\end{array}$ & $\begin{array}{l}\text { Ambulatory } \\
\text { symptomatic HF } \\
\text { patients with LVEF } \\
\leq 45 \%\end{array}$ & $\begin{array}{l}\text { Change } 6 \text { MWT } \\
\text { distance from } \\
\text { baseline to Week } \\
24\end{array}$ & $\begin{array}{l}\text { Sustainable } \\
\text { improvement in } \\
\text { functional } \\
\text { capacity, } \\
\text { symptoms, and } \\
\text { QoL in patients } \\
\text { treated with FCM }\end{array}$ \\
\hline EFFECT HF & 172 & $\begin{array}{l}\text { Prospective } \\
\text { randomized } \\
\text { controlled } \\
\text { multicenter } \\
\text { open-label trial } \\
\text { with blinded } \\
\text { end-point } \\
\text { evaluation }\end{array}$ & $\begin{array}{l}\text { FCM as an undiluted } \\
\text { intravenous bolus } \\
\text { injection or an infusion } \\
\text { of } 500 \text { or } 1,000 \mathrm{mg} \\
\text { administered diluted in } \\
\approx 100 \mathrm{~mL} \text { of sodium } \\
\text { chloride solution and } \\
\text { given in } \geq 6 \text { min for } \\
10 \mathrm{~mL}\end{array}$ & $\begin{array}{l}\text { HFrEF (LVEF } \leq \\
45 \%)\end{array}$ & $\begin{array}{l}\text { Change in peak } \\
\mathrm{VO}_{2} \text { from baseline } \\
\text { to } 24 \text { weeks } \\
\text { measured by } \\
\text { CPET }\end{array}$ & $\begin{array}{l}\text { Favorable effect } \\
\text { on peak VO2 was } \\
\text { observed in } \\
\text { patients treated } \\
\text { with FCM. }\end{array}$ \\
\hline AFFIRM-AHF & 1,132 & $\begin{array}{l}\text { Double-blind } \\
\text { placebo-controlled } \\
\text { randomized }\end{array}$ & $\begin{array}{l}\text { FCM administered as } \\
\text { an undiluted bolus } \\
\text { injection }\end{array}$ & $\begin{array}{l}\text { Patients Admitted } \\
\text { for Acute Heart } \\
\text { Failure with LVEF } \\
<50 \%\end{array}$ & $\begin{array}{l}\text { The composite of } \\
\text { recurrent } \mathrm{HF} \\
\text { hospitalizations } \\
\text { and } \mathrm{CV} \text { death up } \\
\text { to } 52 \text { weeks }\end{array}$ & $\begin{array}{l}\text { Pts actively treated } \\
\text { had significantly } \\
\text { fewer } \\
\text { hospitalization for } \\
\text { HF }\end{array}$ \\
\hline
\end{tabular}

Pts, patients; FCM, ferric carboxymaltose; iv, intravenous; LVEF, left ventricular ejection fraction; HFrEF, heart failure with reduced ejection fraction; 6MWT, six minute walking test; CPET, cardiopulmonary exercise test.

To date, sufficient evidence indicates that the treatment of iron depleted chronic patients with HF and a reduced left ventricular ejection fraction with FCM is associated with improved functional capacity and quality of life.

On the basis of this evidence, the ESC guidelines recommend FCM for symptomatic patients with HF and a reduced ejection fraction with ID (defined by serum ferritin $<100 \mu \mathrm{g} / \mathrm{L}$, or ferritin between 100 and $299 \mu \mathrm{g} / \mathrm{L}$ and TSAT < 20\%) to improve symptoms and functional capacity. This is a class IIa recommendation with a level of evidence of $A$ (5).

Even if no clinical trials have been designed to demonstrate the benefit of iron therapy in patients with
HF, in terms of decreases in hospitalization or other hard clinical endpoints, some promising preliminary data have been reported.

A possible clinical benefit has been suggested by a post-hoc sensitivity analysis of the CONFIRM trial. The composite risk of first hospitalization due to worsening HF or all-cause death has been found to be significantly lower in actively treated patients, with an HR of $0.53(0.30-0.95) p=0.03(50)$.

Two recent meta-analyses $(51,52)$ have shown that FCM significantly decreases hospitalization, cardiovascular and total mortality, and improves the functional class, exercise capacity and quality of life in patients with HF. 
Approximately 800 patients treated with FCM had a lower rate of cardiovascular hospitalization and $\mathrm{CV}$ mortality (rate ratio $0.59)$ compared to control group. Treatment with FCM decreased the all-cause mortality (rate ratio 0.59) (51).

In an exploratory hypothesis generating analysis, Grote Beverborg et al. have evaluated the effect of FCB in the patients included in these meta-analyses, who were selected on the basis of a cutoff of TSAT $\leq 19.8 \%$ and serum iron $\leq 13 \mu \mathrm{mol} / \mathrm{L}$. The authors found out that patients with a TSAT $\leq 19.8 \%$ had improved outcomes after treatment with FCM. In contrast, in patients with low ferritin but TSAT $\geq 19.8$, FCM treatment did not improve outcomes (6).

\section{Iron in Acute HF: The AFFIRM-AHF Trial}

The AFFIRM-AHF trial (a randomized, double-blind, placebo controlled trial comparing the effect of intravenous ferric carboxymaltose on hospitalizations and mortality in iron deficient subjects admitted for acute heart failure) is the first placebo-controlled trial the designed to evaluate the effect of FCM in patients hospitalized for acute HF (53).

The trial enrolled patients hospitalized for acute HF with an ejection fraction $<50 \%$. Most patients were in NYHA class II or III.

According to the definition of ID used in previous studies, patients were required to have a serum ferritin $<100 \mu \mathrm{g} / \mathrm{L}$, or $100-299 \mu \mathrm{g} / \mathrm{L}$ with TSAT $<20 \%$ to be eligible.

Patients were randomized to active treatment with FCM or placebo.

Patients in the active treatment group received the first dose of FCM shortly before discharge from the hospital and the second dose at week 6. Maintenance doses were given at weeks 12 and 24 if ID persisted. However, $80 \%$ of patients required only one or two infusions.

Among 1,525 patients, 567 were randomized to FCM. The primary endpoint of the study was a composite of $\mathrm{HF}$ hospitalizations and cardiovascular death during a 1 year follow-up.

The patients randomized to active treatment had a lower prevalence of the primary endpoint (293 vs. 372, RR 0.79, $95 \%$ CI $0.62-1.01)$, with marginal statistical significance $(p=$ $0.059)$. Patients who were actively treated had significantly fewer hospitalizations for HF: rate ratio $0.79(0.58-0.94, p=0.013)$. The secondary endpoint, a composite of first HF hospitalization or cardiovascular death, was reduced hazard ratio 0.80 (066-0.98, $p=0.030)$.

Because the course of the trial was influenced by the COVID19 pandemic, a sensitive analysis in which patients were censored in each country on the date when the first patients with COVID19 were reported in the respective country, was performed. This analysis confirmed the significant decrease in of HF hospitalizations in treated patients, regardless of the presence of anemia.

This trial suggests several relevant clinical implications, most notably that ID is a modifiable risk factor for hospitalization. According to the AFFIRM-AHF trial, during the acute phase of the disease, when hospitalization is required, ID should be verified, (dosing ferritin and TSAT) and treated with FCM. Treatment should be started before discharge.

\section{ONGOING STUDIES}

Some ongoing trials have been designed to explore the benefit of treatment of ID at different points during the trajectory of HF (54).

\section{FAIR-HFpEF}

The Effect of IV Iron in Patients with HF With Preserved Ejection Fraction study addressed whether treatment with FCM for patients with HF with a preserved ejection fraction and ID might improve exercise capacity, and symptoms.

\section{HEART-FID}

The Randomized Placebo-controlled Trial of FCM as Treatment for Heart Failure with Iron Deficiency trial is a double-blind, multicenter, prospective, randomized, placebo-controlled study designed to assess the effects of IV FCM compared with the placebo in terms of rate of death, hospitalization for worsening $\mathrm{HF}$ and 6-month change in 6MWT.

\section{FAIR-HF2}

The Intravenous Iron in Patients with Systolic Heart Failure and Iron Deficiency to Improve Morbidity \& Mortality trial was designed to assess whether long-term therapy with FCM

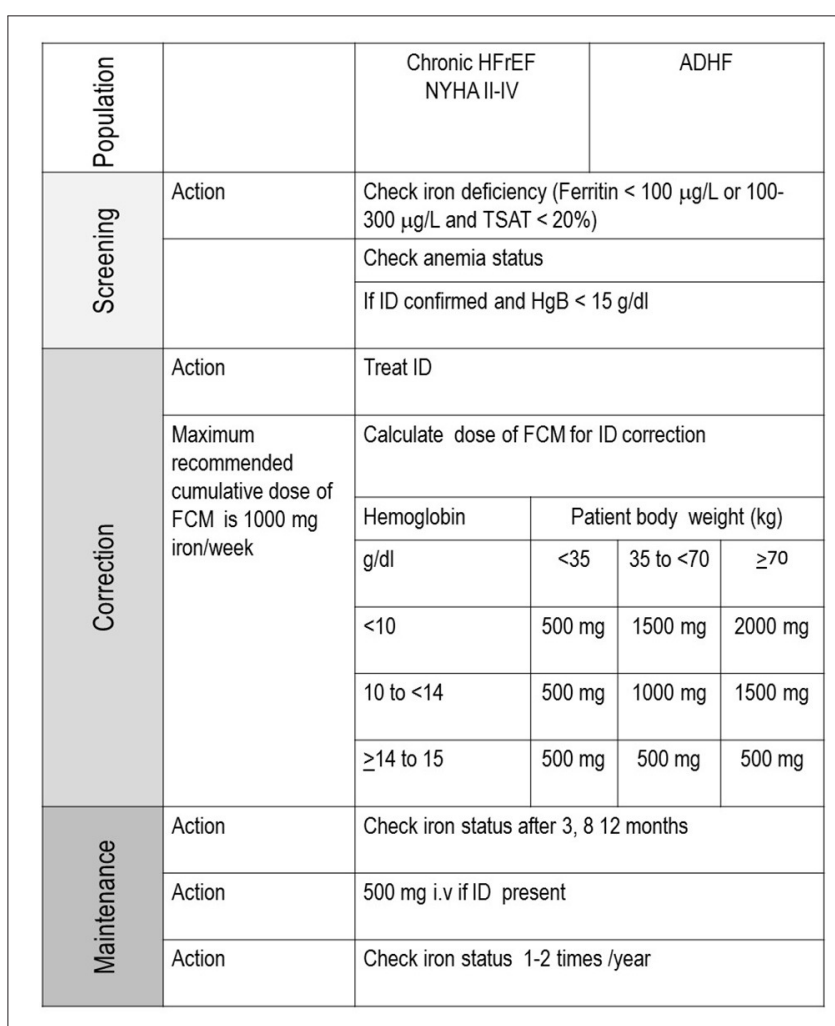

FIGURE 2 | Algorithm for diagnosis and treatment of ID. 
compared with placebo might decrease the rate of recurrent HF hospitalizations and cardiovascular death in patients with HF with a reduced ejection fraction.

\section{IRONMAN}

The Intravenous Iron Treatment in Patients With HF and ID study will address whether the additional use of intravenous iron administered as iron (III) isomaltoside 1,000 iron will improve clinical outcomes for patients with HF and ID.

\section{CONCLUSION}

Several lines of evidence indicate that ID is a target for therapy for both acute and chronic HF.

Patients with symptomatic HF should be screened for ID during both the chronic stable phase than during acute decompensation requiring hospitalization.

FCM infusion should be administered in patients with $\mathrm{HF}$ with a reduced ejection fraction in whom ID is confirmed, to

\section{REFERENCES}

1. Correale M, Paolillo S, Mercurio V, Limongelli G, Barillà F, Ruocco G, et al. Comorbidities in chronic heart failure: an update from Italian Society of Cardiology (SIC) working group on heart failure. Eur J Intern Med. (2020) 71:23-31. doi: 10.1016/j.ejim.2019.10.008

2. Cappellini MD, Comin-Colet J, de Francisco A, Dignass A, Doehner W, Carolyn S, et al. Iron deficiency across chronic inflammatory conditions: international expert opinion on definition, diagnosis and management. Am J Hematol. (2017) 92:1068-78. doi: 10.1002/ajh.24820

3. Wish JB. Assessing iron status: beyond serum ferritin and transferrin saturation. Clin J Am Soc Nephrol. (2006) 1 (Suppl. 1):S4-8. doi: 10.2215/CJN.01490506

4. Nanas JN, Matsouka C, Karageorgopoulos D, Leonti A, Tsolakis E, Drakos SG, et al. Etiology of anemia in patients with advanced heart failure. J Am Coll Cardiol. (2006) 48:2485-9. doi: 10.1016/j.jacc.2006.08.034

5. Ponikowski P, Voors AA, Anker SD, Bueno H, Cleland JGF, Coats AJS, et al. 2016 ESC Guidelines for the diagnosis and treatment of acute and chronic heart failure: the task force for the diagnosis and treatment of acute and chronic heart failure of the European society of cardiology (ESC). Developed with the special contribution of the heart failure association (HFA) of the ESC. Eur J Heart Fail. (2016) 18:891-975. doi: 10.1002/ejhf.592

6. Grote Beverborg N, Klip IT, Meijers WC, Voors AA, Vegter EL, van der Wal HH, et al. Definition of iron deficiency based on the gold standard of bone marrow iron staining in heart failure patients. Circ Heart Fail. (2018) 11:e004519. doi: 10.1161/CIRCHEARTFAILURE.117.004519

7. von Haehling S, Gremmler U, Krumm M, Mibach F, Schön N, Taggeselle J, et al. Prevalence and clinical impact of iron deficiency and anaemia among outpatients with chronic heart failure: the PrEP Registry. Clin Res Cardiol. (2017) 106:106436-43. doi: 10.1007/s00392-016-1073-y

8. Klip IT, Comin-Colet J, Voors AA, Ponikowski P, Enjuanes C, Banasiak W, et al. Iron deficiency in chronic heart failure: an international pooled analysis. Am Heart J. (2013) 165:575-82.e3. doi: 10.1016/j.ahj.2013.01.017

9. Rocha BML, Cunha GJL, Menezes Falcão LF. The burden of iron deficiency in heart failure: therapeutic approach. J Am Coll Cardiol. (2018) 71:782-93. doi: 10.1016/j.jacc.2017.12.027

10. Bhattacharya PT, Misra SR, Hussain M. Nutritional aspects of essential trace elements in oral health and disease: an extensive review. Scientifica. (2016) 2016:12. doi: 10.1155/2016/5464373

11. Anand IS, Gupta P. Anemia and iron deficiency in heart failure. Current concepts and emerging therapies. Circulation. (2018) 138:80-98. doi: 10.1161/CIRCULATIONAHA.118.030099 improve functional capacity, and in patients with acute HF, to reduce re-hospitalization after discharge (Figure 2).

Ongoing trials will demonstrate whether treating ID may improve clinical outcomes in patients with chronic HF with both reduced and preserved ejection fractions.

\section{AUTHOR CONTRIBUTIONS}

AP and DS contributed to conception and design of the review. AP, CR, RR, and RC wrote sections of the manuscript. All authors contributed to manuscript revision, read, and approved the submitted version.

\section{FUNDING}

This study received funding from Ethos srl. The funder was not involved in the study design, collection, analysis, interpretation of data, the writing of this article or the decision to submit it for publication.

12. Stugiewicz M, Tkaczyszyn M, Kasztura M, Banasiak W, Ponikowski P, Jankowska EA. The influence of iron deficiency on the functioning of skeletal muscles: experimental evidence and clinical implications. Eur J Heart Fail. (2016) 18:762-73. doi: 10.1002/ejhf.467

13. Von Haehling S, Ebner N, Evertz R, Ponikowski P, Anker SD. Iron deficiency in heart failure: an overview. JACC Heart Fail. (2018) 7:36-46. doi: 10.1016/j.jchf.2018.07.015

14. Oexle H, Gnaiger E, Weiss G. Iron-dependent changes in cellular energy metabolism: influence on citric acid cycle and oxidative phosphorylation. Biochim Biophys Acta. (1999) 1413:99-107. doi: 10.1016/S0005-2728(99)00088-2

15. Torti FM, Torti SV. Regulation of ferritin genes and protein. Blood. (2002) 99:3505-16. doi: 10.1182/blood.V99.10.3505

16. Hoes MF, Grote Beverborg N, Kijlstra JD, Kuipers J, Swinkels DW, Giepmans $\mathrm{BNG}$, et al. Iron deficiency impairs contractility of human cardiomyocytes through decreased mitochondrial function. Eur J Heart Fail. (2018) 20:910-9. doi: 10.1002/ejhf.1154

17. Xu W, Barrientos T, Mao L, Rockman HA, Sauve AA, Andrews NC. Lethal cardiomyopathy in mice lacking transferrin receptor in the heart. Cell Rep. (2015) 13:533-45. doi: 10.1016/j.celrep.2015.09.023

18. McDonagh T, Macdougall IC. Iron therapy for the treatment of iron deficiency in chronic heart failure: intravenous or oral? Eur J of Heart Fail. (2015) 17:248-62. doi: 10.1002/ejhf.236

19. Jankowska EA, Malyszko J, Ardehali H, Koc-Zorawska E, Banasiak W, Von Haeling S et al. Iron status in patients with chronic heart failure. Eur Heart J. (2013) 34:827-34. doi: 10.1093/eurheartj/ehs377

20. Westenbrink BD, Voors AA, van Veldhuisen DJ. Is anemia in chronic heart failure caused by iron deficiency? Am Coll Cardiol. (2007) 49:2301-2. doi: 10.1016/j.jacc.2007.04.003

21. Caramelo C, Justo S, Gil P. Anemia in heart failure: pathophysiology, pathogenesis, treatment, and incognitae. Rev Esp Cardiol. (2007) 60:848-60 doi: 10.1016/S1885-5857(08)60029-8

22. Grote Beverborg NG, Van Veldhuisen DJ, Van der Meer P. Anemia in heart failure. Still relevant? JACC Heart Fail. (2018) 6:201-8. doi: 10.1016/j.jchf.2017.08.023

23. Okonko DO, Mandal AK, Missouris CG, Poole-Wilson PA. Disordered iron homeostasis in chronic heart failure: prevalence, predictors, and relation to anemia, exercise capacity, and survival. J Am Coll Cardiol. (2011) 58:1241-51. doi: 10.1016/j.jacc.2011.04.040

24. Ebner N, Jankowska EA, Ponikowski P, Lainscak M, Elsner S, Sliziuk V et al. The impact of iron deficiency and anaemia on exercise capacity and outcomes in patients with chronic heart failure. Results from the studies 
investigating co-morbidities aggravating heart failure. Int J Cardiol. (2016) 205:6-12. doi: 10.1016/j.ijcard.2015.11.178

25. Jankowska EA, Rozentryt P, Witkowska A, Nowak J, Hartmann O, Ponikowska B et al. Iron deficiency predicts impaired exercise capacity in patients with systolic chronic heart failure. J Card Fail. (2011) 17:899-906. doi: 10.1016/j.cardfail.2011.08.003

26. Comin-Colet J, Enjuanes C, Gonzalez G, Torrens A, Cladellas M, Merono O, et al. Iron deficiency is a key determinant of health-related quality of life in patients with chronic heart failure regardless of anaemia status. Eur J Heart Fail. (2013) 15:1164-72. doi: 10.1093/eurjhf/hft083

27. Martens P, Nijst P, Verbrugge FH, Smeets K, Dupont M, Mullens W. Impact of iron deficiency on exercise capacity and outcome in heart failure with reduced, mid-range and preserved ejection fraction. Acta Cardiol. (2018) 73:115-23. doi: 10.1080/00015385.2017.1351239

28. Grote Beverborg N, Haye H, van der Wal HH, IJsbrand T, Klip IT, Stefan $\mathrm{D}$ et al. Differences in clinical profile and outcomes of low iron storage vs defective iron utilization in patients with heart failure: results from the DEFINE-HF and BIOSTAT-CHF studies. JAMA Cardiol. (2019) 4:696-701. doi: 10.1001/jamacardio.2019.1739

29. Campodonico J, Nicoli F, Motta I, Migone De Amicis M, Bonomi A et al. Prognostic role of transferrin saturation in heart failure patients. Eur J Prev Cardiol. (2021) 23:zwaa112. doi: 10.1093/eurjpc/zwaa112

30. Núñez J, Comín-Colet J, Miñana G, Núñez E, Santas E, Mollar A, et al. Iron deficiency and risk of early readmission following a hospitalization for acute heart failure. Eur J Heart Fail. (2016) 18:798-802. doi: 10.1002/ejhf.513

31. González-Costello J, Comín-Colet J, Lupón J, Enjuanes C, de Antonio M, Fuentes $\mathrm{L}$ et al. Importance of iron deficiency in patients with chronic heart failure as a predictor of mortality and hospitalizations: insights from an observational cohort study. BMC Cardiovasc Disord. (2018) 18:206. doi: 10.1186/s12872-018-0942-x

32. Jankowska EA, Kasztura M, Sokolski M, Bronisz M, Nawrocka S, OleskowskaFlorek W, et al. Iron deficiency defined as depleted iron stores accompanied by unmet cellular iron requirements identifies patients at the highest risk of death after an episode of acute heart failure. Eur Heart J. (2014) 35:2468-76. doi: 10.1093/eurheartj/ehu235

33. Al-Ahmad A, Rand WM, Manjunath G, Konstam MA, Salem DN, Levey AS, et al. Reduced kidney function and anemia as risk factors for mortality in patients with left ventricular dysfunction. J Am Coll Cardiol. (2001) 38:955-62. doi: 10.1016/S0735-1097(01)01470-X

34. Go AS, Yang J, Ackerson LM, Lepper K, Robbins S, Massie BM, et al. Hemoglobin level, chronic kidney disease, and the risks of death and hospitalization in adults with chronic heart failure: the anemia in chronic heart failure: outcomes and resource utilization (ANCHOR) study. Circulation. (2006) 113:2713-23 doi: 10.1161/CIRCULATIONAHA.105.577577

35. Adams KF Jr, Patterson JH, Oren RM, Mehra MR, O’Connor CM, Piña IL, et al. Prospective assessment of the occurrence of anemia in patients with heart failure: results from the study of anemia in a heart failure population (STAMINA-HFP) registry. Am Heart J. (2009) 157:926-32. doi: 10.1016/j.ahj.2009.01.012

36. Young JB, Abraham WT, Albert NM, Gattis Stough W, Gheorghiade $\mathrm{M}$, Greenberg $\mathrm{BH}$, et al. Relation of low hemoglobin and anemia to morbidity and mortality in patients hospitalized with heart failure (insight from the OPTIMIZE-HF registry). Am J Cardiol. (2008) 101:223-30. doi: 10.1016/j.amjcard.2007.07.067

37. Tang YD, Katz SD. Anemia in chronic heart failure: prevalence, etiology, clinical correlates, and treatment options. Circulation. (2006) 113:2454-61. doi: 10.1161/CIRCULATIONAHA.105.583666

38. Silverberg DS, Wexler D, Blum M, Keren G, Sheps D, Leibovitch E, et al. The use of subcutaneous erythropoietin and intravenous iron for the treatment of the anemia of severe, resistant congestive heart failure improves cardiac and renal function and functional cardiac class, and markedly reduces hospitalizations. J Am Coll Cardiol. (2000) 35:1737-44. doi: 10.1016/S0735-1097(00)00613-6

39. Silverberg DS, Wexler D, Sheps D, Blum M, Keren G, Baruch R, et al. The effect of correction of mild anemia in severe, resistant congestive heart failure using subcutaneous erythropoietin and intravenous iron: a randomized controlled study. J Am Coll Cardiol. (2001) 37:1775-80. doi: 10.1016/S0735-1097(01)01248-7

40. Mancini DM, Katz SD, Lang CC, LaManca J, Hudaihed A, Androne AS. Effect of erythropoietin on exercise capacity in patients with moderate to severe chronic heart failure. Circulation. (2003) 107:294-9. doi: 10.1161/01.CIR.0000044914.42696.6A

41. Palazzuoli A, Silverberg D, Iovine F, Capobianco S, Giannotti G, Calabrò A, et al. Erythropoietin improves anemia exercise tolerance and renal function and reduces B-type natriuretic peptide and hospitalization in patients with heart failure and anemia. Am Heart J. (2006) 152:1096.e9-15. doi: 10.1016/j.ahj.2006.08.005

42. Ponikowski P, Anker SD, Szachniewicz J, Okonko D, Ledwidge M, Zymlinski R, et al. Effect of darbepoetin alfa on exercise tolerance in anemic patients with symptomatic chronic heart failure: a randomized, double-blind, placebo-controlled trial. J Am Coll Cardiol. (2007) 49:753-62. doi: 10.1016/j.jacc.2006.11.024

43. van Veldhuisen DJ, Dickstein K, Cohen-Solal A, Lok DJ, Wasserman SM, Baker N, et al. Randomized, double-blind, placebo-controlled study to evaluate the effect of two dosing regimens of darbepoetin alfa in patients with heart failure and anaemia. Eur Heart J. (2007) 28:2208-16. doi: 10.1093/eurheartj/ehm328

44. Ghali JK, Anand IS, Abraham WT, Fonarow GC, Greenberg B, Krum $\mathrm{H}$, et al. Study of anemia in heart failure trial (STAMINA-HeFT) group. Randomized double blind trial of darbepoetin alfa in patients with symptomatic heart failure and anemia. Circulation. (2008) 117:526-35. doi: 10.1161/CIRCULATIONAHA.107.698514

45. Swedberg K, Young JB, Anand IS, Cheng S, Desai AS, Diaz R, et al. Treatment of anemia with darbepoetin alfa in systolic heart failure. N Engl J Med. (2013) 368:1210-9. doi: 10.1056/NEJMoa1214865

46. Lewis GD, Malhotra R, Hernandez AF, McNulty SE, Smith A, Felker GM, et al. Effect of oral iron repletion on exercise capacity in patients with heart failure with reduced ejection fraction and iron deficiency: the IRONOUT HF randomized clinical trial. JAMA. (2017) 317:1958-66. doi: 10.1001/jama.2017.5427

47. Okonko DO, Grzeslo A, Witkowski T, Mandal AK, Slater RM, Roughton $\mathrm{M}$, et al. Effect of intravenous iron sucrose on exercise tolerance in anemic and nonanemic patients with symptomatic chronic heart failure and iron deficiency FERRIC-HF: a randomized, controlled, observer-blinded trial. $J$ Am Coll Cardiol. (2008) 51:103-12. doi: 10.1016/j.jacc.2007.09.036

48. Anker SD, Comin Colet J, Filippatos G, Willenheimer R, Dickstein K, Drexler $\mathrm{H}$, et al. FAIR-HF trial investigators. Ferric carboxymaltose in patients with heart failure and iron deficiency. N Engl J Med. (2009) 361:2436-48. doi: 10.1056/NEJMoa0908355

49. McMurray JJ, Adamopoulos S, Anker SD, Auricchio A, Böhm M, Dickstein $\mathrm{K}$, et al. ESC guidelines for the diagnosis and treatment of acute and chronic heart failure 2012: the task force for the diagnosis and treatment of acute and chronic heart failure 2012 of the European society of cardiology. Developed in collaboration with the Heart Failure Association (HFA) of the ESC. Eur Heart J. (2012) 33:1787-847. doi: 10.1093/eurheartj/ehs104

50. Ponikowski P, van Veldhuisen DJ, Comin-Colet J, Ertl G, Komajda M, Mareev V, et al. CONFIRM-HF investigators. Beneficial effects of longterm intravenous iron therapy with ferric carboxymaltose in patients with symptomatic heart failure and iron deficiency. Eur Heart J. (2015) 36:657-68. doi: 10.1093/eurheartj/ehu385

51. Anker SD, Kirwan BA, van Veldhuisen DJ, Filippatos G, Comin-Colet J, Ruschitzka F, et al. Effects of ferric carboxymaltose on hospitalisations and mortality rates in iron-deficient heart failure patients: an individual patient data meta-analysis. Eur J Heart Fail. (2018) 20:125-33. doi: 10.1002/ ejhf. 823

52. Jankowska EA, Tkaczyszyn M, Suchocki T, Drozd M, von Haehling S, Doehner $\mathrm{W}$, et al. Effects of intravenous iron therapy in iron-deficient patients with systolic heart failure: a meta-analysis of randomized controlled trials. Eur J Heart Fail. (2016) 18:786-95. doi: 10.1002/ejhf.473

53. Ponikowski P, Kirwan BA, Anker SD, McDonagh T, Dorobantu M, Drozdz J, et al. Ferric carboxymaltose for iron deficiency at discharge after acute heart failure: a multicentre, double-blind, randomised, controlled trial. Lancet. (2020) 396:1895-904. doi: 10.1016/S0140-6736(20)32339-4 
54. NIH. Explore 383,811 Research Studies in all 50 States and in 220 Countries. Available online at: https://clinicaltrials.gov/ct2/home (accessed April 10, 2021).

Conflict of Interest: The authors declare that the research was conducted in the absence of any commercial or financial relationships that could be construed as a potential conflict of interest.

Publisher's Note: All claims expressed in this article are solely those of the authors and do not necessarily represent those of their affiliated organizations, or those of the publisher, the editors and the reviewers. Any product that may be evaluated in this article, or claim that may be made by its manufacturer, is not guaranteed or endorsed by the publisher.

Copyright (c) 2021 Rizzo, Carbonara, Ruggieri, Passantino and Scrutinio. This is an open-access article distributed under the terms of the Creative Commons Attribution License (CC BY). The use, distribution or reproduction in other forums is permitted, provided the original author(s) and the copyright owner(s) are credited and that the original publication in this journal is cited, in accordance with accepted academic practice. No use, distribution or reproduction is permitted which does not comply with these terms. 